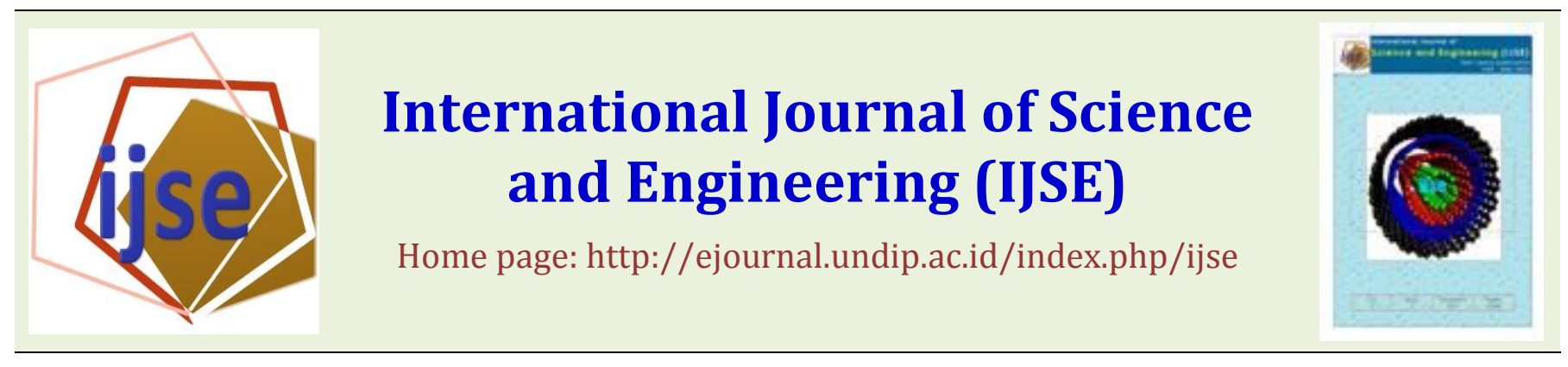

\title{
Physical and Mechanical Properties of Palm Oil Frond and Stem Bunch for Developing Pruner and Harvester Machinery Design
}

\author{
Yazid Ismi Intara1), H. Mayulu²) and P.A.S. Radite3) \\ 1)Agro-technology Department of Agricultural Faculty, Mulawarman University \\ 2)Animal Sciences Department of Agricultural Faculty, Mulawarman University \\ ${ }^{3)}$ Mechanical and Biosystem Department of Agricultural Technology Faculty, Bogor Agricultural University.
}

1Email: izmi_6@yahoo.com

\begin{abstract}
A development of oil palm pruner and harvester machinery design implemented in the field still faces a problem due to the lack of effective and efficient design which is need to be solved. It was noted that in order to develop the design, an early data and information of physical and mechanical properties of palm oil frond and stem fruits is critically important. The objective of the research was to obtain the physical and mechanical properties of palm oil frond and stem in order to develop the design of pruner and harvester machinery. The result showed that tool machinery was been advantageous by the physical properties of the plant i.e. the total weight of frond and leaf which enable to support the cutting process. The average of total weight of frond and leaf was $16.8 \mathrm{~kg}$. The diagonal cutting trajectory was been more advantageous because of total weight and frond shape toward to the different of the plant tissue area. The measurement result shows that cutting curve follows the time required for cutting. The comparison among cutting curve shows differences in cutting thickness or length. In this case, the thickness is linear with cutting time. Besides, those curves show differences at the height which determine the maximum value of tested material cutting resistance. Alternative solution for machinery development design is pruner-harvester for height plant below $6 \mathrm{~m}$ and among 6 to $12 \mathrm{~m}$. For below $6 \mathrm{~m}$, pruner-harvester was designed by incorporating motor as power source and cutter-disc as the knife cutter. That condition was relied on that estate which was maintenance intensively commonly used cutter-disc. Pruner-harvester above $6 \mathrm{~m}$ and up to $12 \mathrm{~m}$ was improved based on manual egrekdesigned by adding fresh fruit bunch alley supply glide in order to keep the fruits still in intact form. The consideration was based on affectivity and efficiency. It also considers homogenous ecological of palm oil plant which should be maintained to reduce global warming effect. Information obtained in this research could become positive consideration and alternative solution to provide problem solvingat early development design of palm oil pruner and harvester machinery.
\end{abstract}

Keywords - physical-mechanical properties, palm oil frond, stem bunch, design, pruner, palm oil harvester

Submission: December 19, 2012
Doi: http://dx.doi.org/10.12777/ijse.4.2.2013.69-74

Corrected : March 3, 2013

Accepted: March 11, 2013

\section{INTRODUCTION}

A harvesting process of palm oil is a cutting mechanism of the frond and stem bunch (Delmastro and Francesco, 1998). A research in cutting mechanism of palm oil harvesting is very important to be conducted in order to develop more effective, efficient and ergonomic to anticipate future global competition (Ahmad et al., 2000). An engineering approach based on cutting mechanism of the frond and stem fruits analysis could be one of the answers. This analysis could provide basic parameter of the blade which enablesto cut the frond and stem bunch efficiently (Yazid et al., 2005a). At this present, the basic research of pruner and harvester palm oil frond and stem has not yet focused to the whole factors of physical, mechanical and structural properties of the plant material toward the cutting mechanism.

Perrson (1987) stated that knowledge of plant structure is very important to generate the reaction of plant material toward the cutting force and deformation. Thus could also provide the easiness to gain logical solution in order to develop cutting tool design. An understanding of the force occurred on a tool should be gained based on the material characteristic. The developed interaction can be not used if there are a different on size and structure between laboratory and real at the field (Holman and Gajda, 1989). 
The plant tissue which will be used as the tested sample has specific mechanical properties. Deflection property is a displacement event of particular elements at the surface fiber in a layer thickness due to the bending which occurs up to underside of pressing area. The bending degree is influenced by the position of fiber in a particular layer and the thickness of the layer. A mathematical modeling of cutting force is highly influenced by the mechanical properties condition of the sample and force vector analysis employed in cutting process. This force will correlate toward the deformation properties of cut material (Yazid, 2005 b).

A harvesting process of palm oil is a cutting mechanism of the frond and stem bunch (Delmastro and Francesco, 1998). A research in cutting mechanism of palm oil harvesting is very important to be conducted in order to develop more effective, efficient and ergonomic to anticipate future global competition (Ahmad et al., 2000). An engineering approach based on cutting mechanism of the frond and stem fruits analysis could be one of the answers. This analysis could provide basic parameter of the blade which enablesto cut the frond and stem bunch efficiently (Yazid et al., 2005a). At this present, the basic research of pruner and harvester palm oil frond and stem has not yet focused to the whole factors of physical, mechanical and structural properties of the plant material toward the cutting mechanism.

Perrson (1987) stated that knowledge of plant structure is very important to generate the reaction of plant material toward the cutting force and deformation. Thus could also provide the easiness to gain logical solution in order to develop cutting tool design. An understanding of the force occurred on a tool should be gained based on the material characteristic. The developed interaction can be not used if there are a different on size and structure between laboratory and real at the field (Holman and Gajda, 1989).

The plant tissue which will be used as the tested sample has specific mechanical properties. Deflection property is a displacement event of particular elements at the surface fiber in a layer thickness due to the bending which occurs up to underside of pressing area. The bending degree is influenced by the position of fiber in a particular layer and the thickness of the layer. A mathematical modeling of cutting force is highly influenced by the mechanical properties condition of the sample and force vector analysis employed in cutting process. This force will correlate toward the deformation properties of cut material (Yazid, 2005 ${ }^{\mathrm{b}}$ ).

During cutting process, the blade penetrates into the material, passing material strength which leads to material become split. In this process, material deformation is different which depends on the blade shape and cutting mechanical process (Sitkei, 1986).

Based on above consideration, the research was conducted to obtain field data and laboratory measurement upon the mechanical properties of palm oil frond and stem. The research was objected to obtain physical and mechanical properties of palm oil frond and stem to develop pruner and harvester machinery design of palm oil bunch.

\section{MATERIAL AND METHOD}

The research was conducted from June - September 2009 in:

1. Laboratory of Plantation Product Technology, PoltanesaSamarinda.

2. Laboratory of Materials Strength, Department of Forest Product Technology, Faculty of Forestry, Mulawarman University,Samarinda.

3. Palm Oil Plantation of Rea Kaltim Co., Tenggarong,KutaiKartanegara.

Materials and tools used were:

1. Universal Testing Machine (UTM) AMSLER (Type 10 Tuzes, Machine Nr 1999)

2. Deflecto meter (Mitutoyo Japan, 0.01 - $10 \mathrm{mms}$, No. 2046-08, Shock Proof)

3. Ruler, Protractor (CCKL Creator, Pat. 4.7666.675)

4. Weighing-meter, Knife Cutter, Dagger.

Figure 1 shows the technique to obtain the research material sample. The parameters which are observed and measured in frond and stem analysis were: a) stem bunch; b) fresh fruit bunch; c) leaf frond. The measurement consisted of: 1) weight and length of a) fresh fruit bunch and b) leaf frond; 2) angle and clearance between: a) stem and trunk; b) leaf frond and trunk; c) frond and frond, d) bunch and frond.

Measurement method to measure mechanical properties is shown in Fig. 2 which conducted to obtain these several parameters:

1. Elasticity Modulus (E)

2. Poisson ratio (v)

3. Yield strength $(\mathrm{s})$

4. Strain (e)

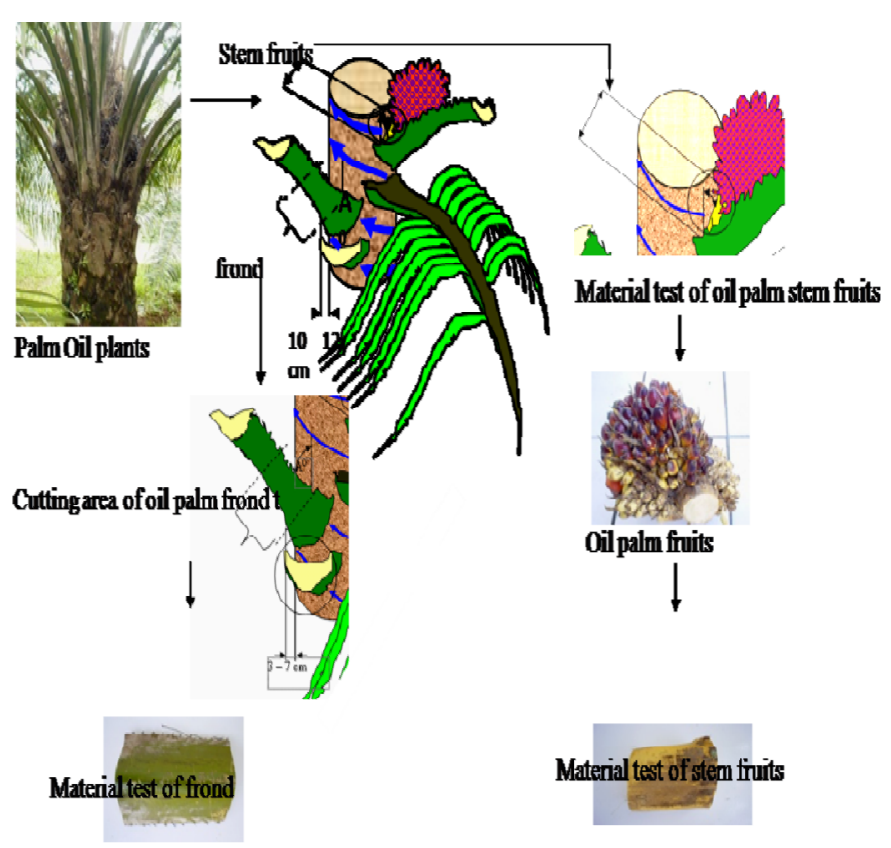

Fig 1.Technique to obtain frond and bunch fruit as material sample which is used in cutting test 


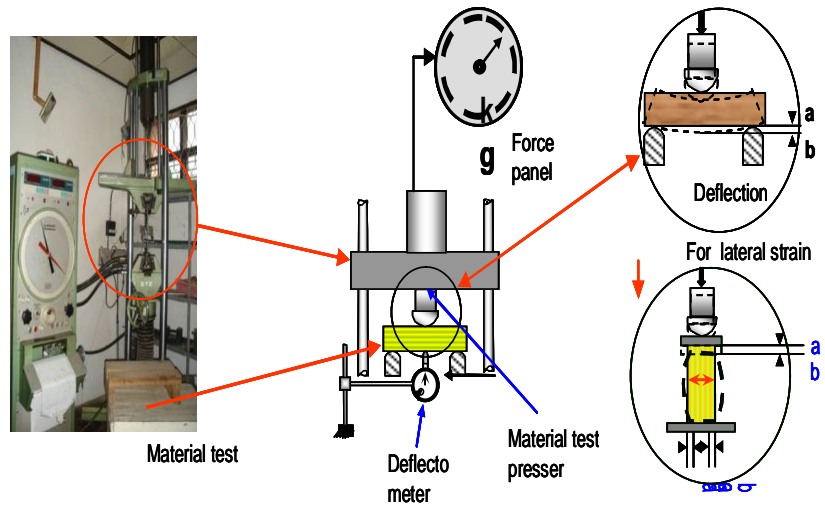

for axialstrain

Fig. 2. Method to measure mechanical properties

of palm oil frond and bunch

Universal Testing Machine which was used in the Laboratory of Materials Strength, Department of Forest Product Technology, Faculty of Forestry of Mulawarman University is shownin Figure 3.
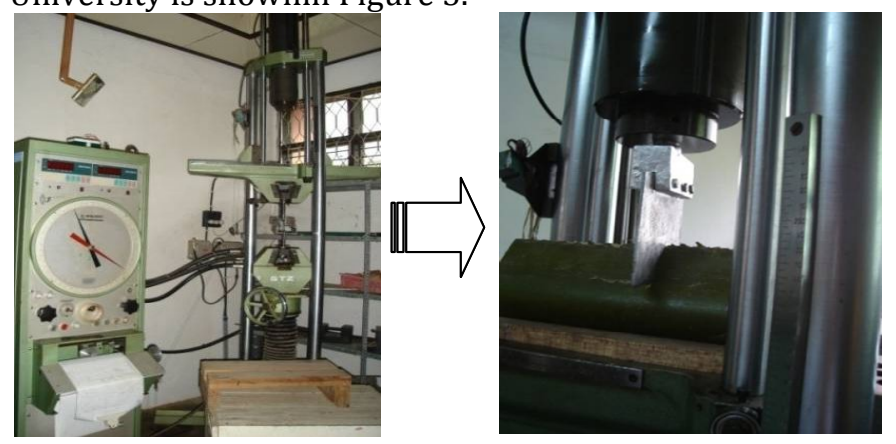

Fig. 3. Apparatus and method to measure cutting force palm oil frond and bunch

\section{RESULT AND DISCUSSION}

An observation of anatomy parts of palm oil frond and bunch is shown in Figure 4 consists of tissues which compose the plant structure. Frond part was composed of hard bark which consists of epidermis, collenchyma and sclerenchyma tissue. The soften part at the middle is parenchyma tissue which is used as material test. The determination of material test was carried out as an earlier research to obtain research of cutting intact frond. Besides, that part was considered as easier to be employed in laboratory test before developing prototype implemented in the field. Thus was supported by Perrson (1987) who stated that knowledge of plant structure is required to understand the reaction of material upon cutting force and deformation. It also eases to find logical solution to develop cutting tool design. Sometimes, some differences between tool which was used in laboratory scale and will be developed to be implemented in the field were occurred.

A characteristic measurement of palm oil bunch and frond was conducted in order to obtain physical properties. The result of physical properties obtained in field measurement is shown in Table 1.
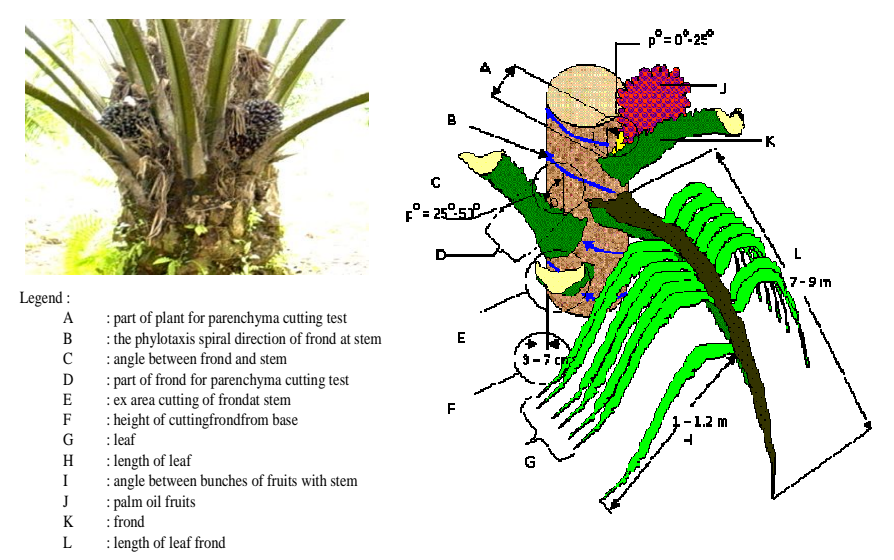

Fig. 5.Parenkhima frond and bunch as tested

material at the field

The design of tool machinery was been advantageous by the physical properties of the plant, i.e. 1) the total weight of frond and leaf enabled to support the cutting process. The total weight of frond and leaf was $16.8 \mathrm{~kg}$ with frond surface area located at $12 \mathrm{~cm}$ from the stem was $96.8 \mathrm{~cm}^{2}$. 2) The diagonal cutting trajectory was been more advantageous because of total weight and frond shape toward to the different of the plant tissue area.The plant tissue which was used as the sample had specific mechanical properties (Hanim and Siti-Norsafurah, 2012).

The cutting specific force analysis was greatly influenced by the mechanical properties of tested agricultural product. The bending degree was influenced by the position of fiber laid on a particular layer and the thickness of the layer. The point which lay on a particular thickness layer experienced bending movement up to the underside of the blade. The mathematic model development of cutting force would be influenced by the mechanical properties of the tested sample. Vector force analysis which occurred at cutting process would associatewith deformation characteristic of the tested sample. The mechanical properties data of a material which was employed in cutting the palm oil parenchyma is showed in Table 2. Material deflection data was gained from stress and strain measurement which was then used to determine modulus elasticity (E), strength $(\sigma)$, strain $(\varepsilon)$, andpoisson ratio $(v)$.

The result of cutting force could be simulated which shows graph in Fig. 6 . In the cutting mechanism of palm oil frond using knife cutter, the length of cutting is the function between time (s) and force $(\mathrm{daN} / \mathrm{cm})$. The measurement of palm oil cutting was conducted at laboratory using flat knife cutter with sharpness angle at $10^{\circ}$ applied in UTM. The frond as tested material was in intact form which was cut at different area i.e. 25\%, 50\% and $75 \%$. 
Table 1. Physical properties of palm oil plant

\begin{tabular}{|c|c|c|c|}
\hline Num & $\begin{array}{c}\text { Part of plant } \\
\text { material }\end{array}$ & Parameter & Size \\
\hline 1 & Frond & $\begin{array}{l}\text { 1. angelbetweenfrond and stem } \\
\text { 2. weight of leaf sandfrond } \\
\text { 3. width of frondat area cutting } \\
\text { 4. area of cutting frond section } \\
\text { 5. clearance of cutting frond from base } \\
\text { 6. length of frondfrom base till leaf end } \\
\text { 7. amount of leaves } \\
\text { 8. length of per leaf } \\
\text { 9. shape of frond sectionis triangle shape }\end{array}$ & $\begin{array}{l}25^{0}-50^{0} \\
5.7-8.3 \mathrm{~kg} \\
15-20 \mathrm{~cm} \\
41.25-62 \mathrm{~cm}^{2} \\
3-7 \mathrm{~cm} \\
7-9 \mathrm{~m} \\
200-320 \text { leaf } \\
1-1.2 \mathrm{~m}\end{array}$ \\
\hline 2 & Stem bunch & $\begin{array}{l}\text { 1. angel between bunch and stem in cutting area } \\
\text { 2. weight of palm oil fresh bunch } \\
\text { 3. diameter of fruit bunch } \\
\text { 4. cutting area of bunch at stem and frond } \\
\text { 5. shape of stem of fruits iselips - circle }\end{array}$ & $\begin{array}{l}0^{0}-35^{0} \\
8-21 \mathrm{~kg} \\
5-7 \mathrm{~cm} \\
6-9.5 \mathrm{~cm} \\
0^{\circ}-15^{\circ}\end{array}$ \\
\hline 3 & $\begin{array}{l}\text { Longitudinal } \\
\text { section of } \\
\text { frond }\end{array}$ & $\begin{array}{l}\text { 1. Epidermis (outer bark which consists of wax layer } \\
\text { andchlorophyl fiber tissue) } \\
\text { 2. Sclerenchymaand colenchyma (the hardest layer) } \\
\text { 3. Parenchyma (soft tissueconsist of fiber) }\end{array}$ & $\begin{array}{l}0.05-0.1 \mathrm{~cm} \\
0.3-0.7 \mathrm{~cm} \\
5-8 \mathrm{~cm}\end{array}$ \\
\hline 4 & $\begin{array}{l}\text { Longitudinal } \\
\text { section of } \\
\text { bunch stem }\end{array}$ & $\begin{array}{l}\text { 1. Epidermis (outer bark which consists wax layer and } \\
\text { chlorophyl fiber tissue ) } \\
\text { 2. Sclerenchyma and colenchyma (the hardest layer) } \\
\text { 3. Parenchyma (soft tissue consists of fiber and pith) }\end{array}$ & $\begin{array}{l}0.05-0.1 \mathrm{~cm} \\
0.2-0.4 \mathrm{~cm} \\
4-5 \mathrm{~cm}\end{array}$ \\
\hline
\end{tabular}

Palm oil plantation of Rea Kaltim Co. Ltd,Tenggarong.East Kalimantan.

Table 2. The mechanical properties of tested material (frond and palm oil bunch)

\begin{tabular}{|c|c|c|c|c|c|c|c|c|c|}
\hline \multirow{2}{*}{$\begin{array}{l}\text { Material } \\
\text { sample test }\end{array}$} & weight & length & deflection & inertia & axial max & \multicolumn{4}{|c|}{ MOE } \\
\hline & $\mathrm{p}$ & $\mathrm{L}$ & \multicolumn{3}{|c|}{ I } & \multicolumn{4}{|c|}{$\mathrm{E}$} \\
\hline $\begin{array}{l}\text { Intact } \\
\text { frond }\end{array}$ & 158 & 0.3 & 0.0112 & 0.0074 & 195.66 & 1070.17 & psi & 104.87 & $\mathrm{daN} / \mathrm{cm}^{2}$ \\
\hline $\begin{array}{l}\text { Stem } \\
\text { bunch }\end{array}$ & 14 & 0.1 & 0.0021 & 0.00026 & 41.66 & 509.66 & psi & 49.94 & $\mathrm{daN} / \mathrm{cm}^{2}$ \\
\hline frond $25 \%$ & 100 & 0.3 & 0.0227 & 0.0074 & & 333.74 & psi & 32.70 & $\mathrm{daN} / \mathrm{cm}^{2}$ \\
\hline frond $50 \%$ & 100 & 0.3 & 0.0202 & 0.0074 & & 374.97 & psi & 36.74 & $\mathrm{daN} / \mathrm{cm}^{2}$ \\
\hline frond $75 \%$ & 100 & 0.3 & 0.0132 & 0.0074 & & 572.92 & psi & 56.14 & $\mathrm{daN} / \mathrm{cm}^{2}$ \\
\hline \multirow{2}{*}{$\begin{array}{l}\text { Material } \\
\text { sample test }\end{array}$} & strain (e) & \multicolumn{2}{|c|}{ yield strength } & $\begin{array}{c}\text { poisson } \\
\text { ratio }\end{array}$ & $\begin{array}{l}\text { Friction } \\
\text { coef. }\end{array}$ & $\begin{array}{l}\text { Blade } \\
\text { thickness }\end{array}$ & \multicolumn{2}{|c|}{$\begin{array}{l}\text { Height of } \\
\text { material }\end{array}$} & wide \\
\hline & $\mathrm{e}$ & \multicolumn{2}{|c|}{$\mathrm{s}=\mathrm{e}^{*} \mathrm{E}$} & $\mathrm{n}$ & $\mathrm{m}$ & $\mathrm{d}$ & \multicolumn{2}{|c|}{$\mathrm{H}$} & \\
\hline $\begin{array}{l}\text { Frond } \\
\text { intact }\end{array}$ & 0.0373 & 3.91 & $\mathrm{daN} / \mathrm{cm}^{2}$ & 0.807 & 0.39 & 0.00015 & & $56 \mathrm{~mm}$ & $152 \mathrm{~mm}$ \\
\hline $\begin{array}{l}\text { Stem of } \\
\text { fruits }\end{array}$ & 0.0214 & 1.07 & $\mathrm{daN} / \mathrm{cm}^{2}$ & 0.336 & 0.34 & 0.00015 & & $42 \mathrm{~mm}$ & $40 \mathrm{~mm}$ \\
\hline
\end{tabular}

The measurement result shows that cutting curve follows the time required for cutting. The comparison among cutting curve shows differences in cutting thickness or length. In this case, the thickness is linear with cutting time. Besides, those curves show differences at the height which determine the maximum value of tested material cutting resistance.

The technical problems occurred during palm oil cutting and harvesting applied in the field is shown in Table 3.

Table 3 shows the importance of developing pruner and harvester design to replace the manual tool in order to provide more effective and efficient palm oil maintenance and harvester process. Further solution is to design pruner-harvester for height below $6 \mathrm{~m}$ and among 6 to 12 $\mathrm{m}$. For below $6 \mathrm{~m}$, pruner-harvester was designed by incorporating motor as power source and cutter-disc as the knife cutter. That condition was relied on that estate which was maintenance intensively commonly used cutter-disc. Pruner-harvester above $6 \mathrm{~m}$ which could reach $12 \mathrm{~m}$ was improved based onmanual egrek-designed by adding fresh fruit bunch alley supply glide in order to keep the fruits still in intact form. The consideration was based on affectivity and efficiency. It also considers homogenous ecological of palm oil plant which should be maintained to reduce global warming effect (to lessen plant rejuvenation and replanting) 

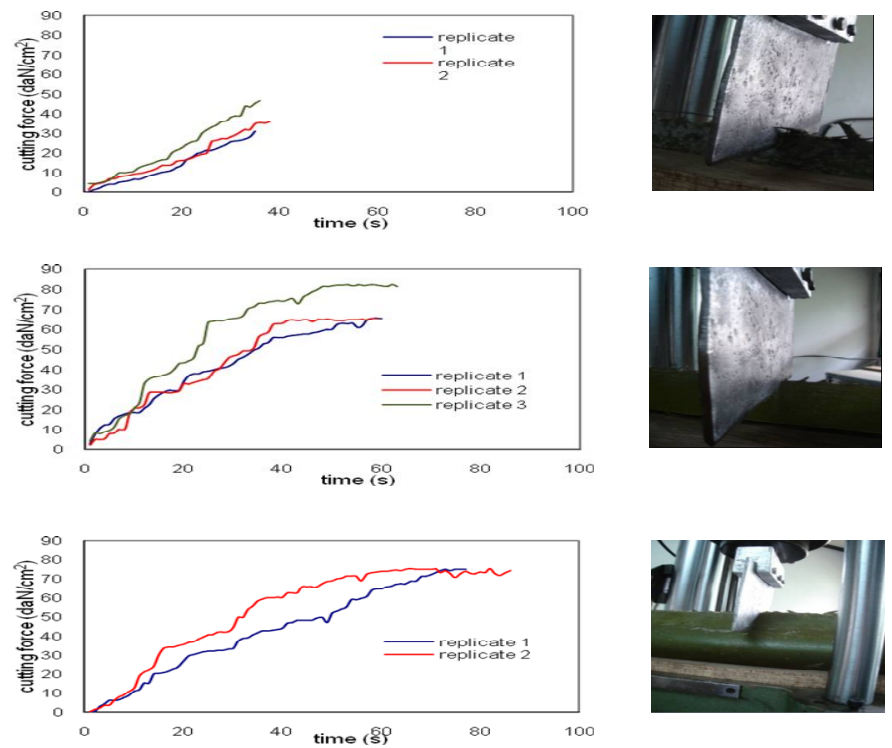

Fig. 6. The measurement result uses flat knife at sharpness $10^{\circ}$ (crosscut angle $=0$ )

\section{IV.CONCLUSION}

1. The cutting frond part was composed of hard bark which consists of epidermis, collenchyma and sclerenchyma tissue. The soften part at the middle is parenchyma tissue which can improve cutting process.
2. The design of tool machinery was been advantageous by the physical properties of the plant, i.e. 1) the total weight of frond and leaf enabled to support the cutting process. The total weight of frond and leaf was $16.8 \mathrm{~kg}$ with frond surface area located at $12 \mathrm{~cm}$ from the stem was $96.8 \mathrm{~cm}^{2}$. The diagonal cutting trajectory was been more advantageous because of total weight and frond shape toward to the different of the plant tissue area.

3. The plant tissue which was used as the sample had specific mechanical properties. The mathematic model development of cutting force would be influenced by the mechanical properties and force vector which associate with deformation characteristic of the tested sample. Material deflection data was gained from stress and strain measurement which was then used for determining modulus elasticity $(E)$, strength $(\sigma)$, strain $(\varepsilon)$, and poisson ratio $(v)$.

4. The measurement result shows that cutting curve follows the time required for cutting. The comparison among cutting curve shows differences in cutting thickness or length. In this case, the thickness is linear with cutting time. Besides, those curves show differences at the height which determine the maximum value of tested material cutting resistance.

5. Further development is to design pruner-harvester for plant height below $6 \mathrm{~m}$ and among 6 to $12 \mathrm{~m}$.

Table 3. Technical problems occurred in palm oil cutting and harvesting in the field

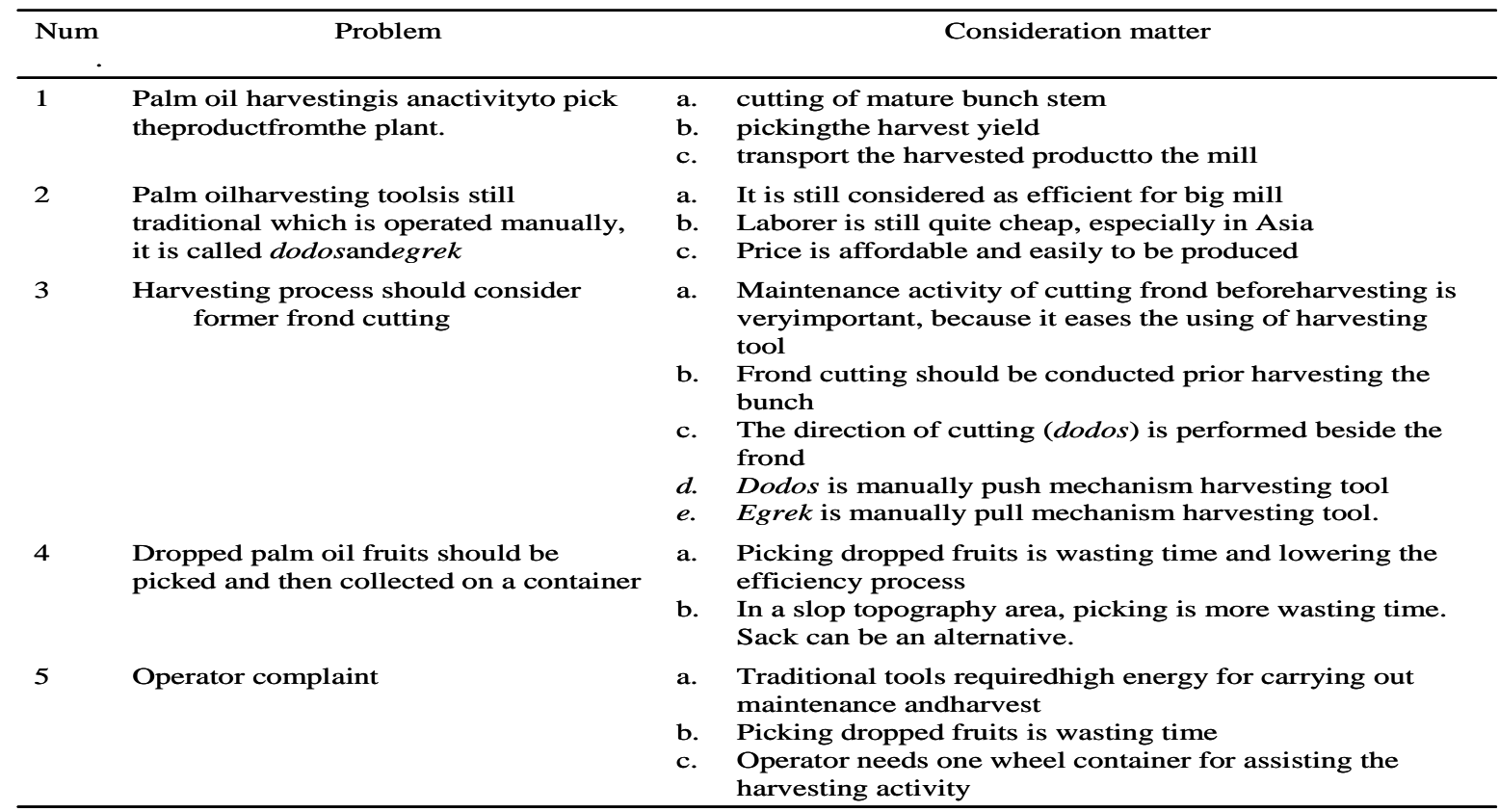

\section{REFERENCES}

[1]. Ahmad, D. S.K Roy dan A.R Jaelani, 2000. Evaluation of Design Parameters of Sicle Cutter and Claw Cutter for Cutting Oil Palm Frond. AMA Journal. 31(2): 55 - 60.
[2]. Delmastro and Francesco, 1998. Mechanized Harvesting of palm fruits. AMA Journal. 29 (4): 53 - 55

[3]. Hanim, S. S. and A. M. Siti-Norsafurah. 2012. Physical properties of hemicellulose films from sugarcane bagasse. Procedia Engineering 42: 1390 - 1395. 
[4]. Holman, J. P. and W.J. Gajda. 1989. Experimental Methods for Engineers (fifth edition) McGraw Hill, Inc. New York.

[5]. Perrson, S. 1987 . Mechanics Of Cutting Plant Material. An ASAE Monograph, St Joseph, Michigan : ASAE

[6]. Sitkey, G. 1986. Mechanics Of Agricultural Matrial. ELSEVIER, Amsteradam.
[7]. Yazid, I. I., I. N Suastawa and Radite P.A.S. 2005. Analysis on specific cutting force of palm oil leaf stem and fruits stem parenchyma. Jurnal Ilmu Keteknikan Pertanian 19 (1): 61 - 70.

[8]. Yazid, I. I., I. N Suastawadan and Radite P.A.S. 2005. Physical and mechanical properties of parenchyma of leaf and fruits stem of palm oil. Jurnal Ilmu Keteknikan Pertanian 19 (2): 117 - 126. 